\title{
Sikap Keberagamaan Masyarakat Muslim Menghadapi Covid-19
}

\author{
Dadang Darmawan ${ }^{1, *}$, Deni Miharja ${ }^{2}$, Roro Sri Rejeki Waluyojati ${ }^{3}$, Erni Isnaeniah ${ }^{4}$ \\ UIN Sunan Gunung Djati Bandung, Indonesia; e-mail: dadangdarmawan@uinsgd.ac.id \\ UIN Sunan Gunung Djati Bandung, Indonesia, e-mail: denimiharja@uinsgd.ac.id \\ UIN Sunan Gunung Djati Bandung, Indonesia, e-mail: rorosrirejekiwaluyojati@uinsgd.ac.id \\ 4 UIN Sunan Gunung Djati Bandung, Indonesia, e-mail: erniisnaeniah@uinsgd.ac.id \\ * Correspondence
}

Received: 2020-03-27; Accepted: 2020-05-27; Published: 2020-05-30

\begin{abstract}
The purpose of this study is to describe the religious attitudes of the Muslim amid COVID19 outbreak. Many muslims are very depressed, because the government and related authorities are trying to ban worship activities in mosques during COVID-19 pandemic. Many Muslims find it hard to leave their custom of worship together at the mosque. Many of them are still praying together in the mosque. This phenomenon is the object of the study. The results show that the pattern of worship activities carried out by Muslims amid COVID-19 pandemic has changed. At the surface level, it appears that mosques tend to be empty and closed. At a deeper level, we see a unique pattern that involves four variables: the obligation of worship, the worship participation, the encouragement of social distancing, and the rationality of Muslims.
\end{abstract}

Keywords: Religious attitude; COVID-19; Social Distancing; Rationality; Muslim community.

Abstrak: Kajian ini bermaksud menguraikan sikap keberagamaan masyarakat muslim di tengah wabah corona virus desease 2019 (COVID-19). Masyarakat beragama saat ini sangat tertekan, terkait dengan kegiatan ibadah yang biasa mereka lakukan, terlebih ketika suatu daerah sudah memberlakukan Pembatasan Sosial Berskala Besar (PSBB), kegiatan berjamaah di masjid pun dibatasi bahkan tidak diperbolehkan. Namun demikian masih banyak umat Islam yang merasa berat untuk meninggalkan kebiasaan mereka beribadah bersama di Mesjid. Masih banyak umat Islam di masa pandemic yang shalat lima waktu berjamaah, shalat jum'at, shalat tarawih berjamaah dan shalat Idul Fitri. Fenomena inilah yang menjadi objek kajian tulisan ini. Hasil kajian yang diperoleh menunjukkan fakta bahwa kegiatan ibadah yang dilakukan oleh masyarakat beragama pada saat pandemi COVID-19 mengalami perubahan. Di tataran permukaan ibadah umat Islam yang awalnya hingar bingar bersifat terbuka di ruang publik saat ini cenderung sepi dan tertutup. Di tataran yang lebih dalam terlihat pola yang unik yang melibatkan empat variable, yakni level ibadah, tingkat partisipasi, anjuran social distancing, dan rasionalitas umat Islam.

Kata Kunci: Sikap Keberagamaan; COVID-19; Social Distancing; Rasionalitas; dan Masyarakat Muslim.

\section{Pendahuluan}

Covid-19 pertama kali muncul di Cina pada akhir tahun 2019 dan mengagetkan seluruh dunia (Daga et al., 2019; Woznitza et al., 2019) kemudian ditetapkan oleh WHO sebagai pandemic pada Maret 2020, seiring semakin banyak negara yang mengalami kasus tersebut (Cucinotta \& Vanelli, 2020; Spinelli \& Pellino, 2020). COVID-19 hingga akhir Maret 2020 sudah merebak di 188 negara dengan jumlah 331.273 orang positif terinfeksi, 97.847 orang yang sembuh dan 13.069 orang meninggal dunia. Di Indonesia sendiri sudah mencapai 510 terinfeksi, 20 orang sembuh dan 38 meninggal dunian (23 Maret 2020).

Negara-negara di dunia berkejaran dengan waktu untuk memutus mata rantai penyebaran COVID-19. Sebagian negara akhirnya melakukan upaya penjarakan fisik dan sosial (social and 
physical distancing) (Wilder-Smith and Freedman, 2020) yang sudah dahulu pernah diterapkan di beberapa kasus serupa sebelumnya (Ahmed, et.al. 2018; Glass, et.al. 2006; Caley, et.al 2008). Sebagiannya lagi bahkan memberlakukan lockdown, penghentian total aktifitas manusia di ruang publik dengan menutup akses transportasi dan pintu keluar-masuk kota atau negara (Lin Q. et.al. 2010; Roosa K., et.al. 2020). Semua negara di dunia menggelontorkan anggaran besar terutama di bidang kesehatan untuk mencegah penyebarannya agar tidak semakin membahayakan. Bukan hanya untuk pembelian alat kesehatan seperti masker, hand sanitizer, alat pelindung diri (APD), rapid test, obat-obatan, tetapi juga membiayai rumah sakit dan laboratorium untuk melakukan riset (Zhang L., Liu Y., 2020).

Pandemi COVID-19 diketahui bermula terjadi di kota Wuhan Tiongkok akhir tahun 2019, dan kemudian menyebar ke seluruh dunia di awal tahun 2020 (Guo et al., 2020), termasuk ke Indonesia. Penyebaran COVID-19 di Indonesia diketahui pada tanggal 2 Maret 2020, dengan terinfeksinya dua orang warga di kota Depok (Djalante et al., 2020; Martha, 2020). Perkembangan pandemi COVID-19 terus bergulir dan menyerang orang-orang yang tidak dapat menjaga jarak (physical and social distancing) (Chen et al., 2020).

Pandemi COVID-19 telah banyak berpengaruh terhadap berbagai sendi-sendi kehidupan. Sudah banyak penelitian yang mengenai pengaruh COVID-19, misalna pengaruhnya terhadap dunia ekonomi (Fernandes, 2020), Pendidikan (Abidah et al., 2020; Cao et al., 2020), pariwisata (Gössling et al., 2020), tak terkecuali kehidupan keagamaan. Penelitian terkait COVID-19 dan keagamaan belum banyak yang melakukan. Salah satu penelitian terkait COVID dan keagamaan adalah (2020) yang meneliti pengaruh COVID-19 terhadap peningkatan seseorang dalam berdoa. Penelitian tersebut masih kurang komprehensif karena data yang diteliti diambil dari hasil pencarian Google.

Pemerintah sudah mengeluarkan aturan yang menganjurkan umat beragama agar beribadah di rumah saja (Peraturan Pemerintah Nomor 21 Tahun 2020 tentang Pembatasan Sosial Berskala Besar Dalam Rangka Percepatan Penanganan Corona Virus Disease 2019 (Covid-19), 2020). Ini untuk mencegah penyebaran COVID-19, terutama untuk daerah zona merah yang sedang menerapkan PSBB. Setiap umat beragama diharuskan menjalankan ibadah di rumahnya masing-masing. Kegiatan ibadah di rumah ini didukung oleh Fatwa Majelis Ulama Indonesia (MUI) (Fatwa Majelis Ulama Indonesia Nomor: 14 Tahun 2020 Tentang Penyelenggaraan Ibadah dalam Situasi Terjadi wabah COVID-19, 2020). Kepatuhan masyarakat beragama terhadap edaran pemerintah dan juga fatwa MUI ini diyakini akan membantu terputusnya mata rantai penyebaran wabah COVID-19. Namun demikian masyarakat muslim dalam kenyataannya mengalami kegelisahan. Mereka mengalami konflik batin antara memenuhi tuntutan iman atau memenuhi tuntutan realitas, Tulisan ini bermaksud membahas dilema tersebut dalam sudut pandang sosiologi agama.

Sikap keberagamaan masyarakat muslim di tengah wabah COVID-19 tentu saja bisa dibaca dari berbagai persektif. Tulisan ini bermaksud untuk membahas masalah ini dari persektif sosiologi agama, dengan meminjam pendekatan yang diperkenalkan oleh Thomas Carlyle sebagaimana dikutip oleh Joahim Wach (1996), juga pendekatan interaksi simbolik yang diperkenalkan oleh Herbert Blumer (1969), penelitian ini juga akan mengemukakan beberapa hasil survey untuk memperkuat analisis yang dilakukan.

\section{Hasil dan Pembahasan}

Bagi Thomas Carlyle (2018) beragama adalah pengalaman yang sangat pribadi dan bermakna. Demikian bermaknanya sehingga orang rela kehilangan nyawa untuk mempertahankannya. Ibarat orang "jatuh cinta", sekuat tenaga ia akan mempertahankan, walapun mungkin seluruh dunia turut menghujatnya. Mengenai hal ini Carlyle (2018, p. 4) berkata:

By religion I do not mean here the church-creed which he professes, the article of faith which he will sign ... This is not what I call religion.... But the thing a man does practically believe ...; the thing a man does practically lay to heart, and know for certain, concerning his vital relations to this mysterious Universe, and his duty and destiny there, that is in all cases the primary thing for him, and creatively determines all the rest. That is his religion. 
[Mengenai agama, yang saya maksud di sini bukanlah doktrin-doktrin yang diucakan, bukan pula pasal-pasal keimanan yang ditanda-tangani.... Itu bukanlah apa yang aku maksud dengan agama.... Tapi (agama adalah) sesuatu yang betul-betul diyakini oleh seorang manusia...; Sesuatu yang sungguh-sungguh tertanam didalam hatinya, dan ia yakin -berdasarkan hubungannya dengan alam semesta yang misterius ini juga dengan tugas dan takdirnya- bahwa hal itulah yang terpenting bagi dirinya dan yang akan menentukan urusan-urusannya. Itulah agama dia yang sesungguhnya...].

Dari perspektif ini, dapatlah dimengerti ungkapan sebagian umat yang mengatakan jangan halangi saya ibadah berjama'ah di masjid, saya tidak takut mati karena Corona, saya lebih takut sama Allah (Ihsom, 2020). Ini karena bagi mereka ibadah berjama'ah di masjid adalah sesuatu yang sangat berarti. Mereka secara personal dan nyata mengalami pengalaman keagamaan yang bermakna saat melaksanakan ibadah di masjid, dan ketika hal itu dilarang, mereka mengalami kegelisahan yang luar biasa. Larangan ibadah berjamaah di masjid membuat mereka kehilangan jati diri. Orang-orang ini mengalami kehilangan spriritual yang besar, walaupun mungkin bagi sebagian besar umat Islam yang lainnya, larangan shalat berjamaah di masjid bukanlah hal yang harus dipusingkan. Toh di harihari sebelumnya pun mereka langka pergi shalat berjamaah ke masjid. Oleh karena itu bagi $80 \%$ (mayoritas) umat Islam, ini bukanlah masalah besar dan mereka tidak merasa kehilangan apapun. Namun bagi sekitar $20 \%$ umat Islam lainnya yang taat, yang terbiasa shalat berjamaah di mesjid, larangan ibadah berjama'ah di masjid adalah masalah yang pelik dan besar (Puslitbang Bimas Agama dan Layanan Keagamaan, 2020).

Untuk memahami hal ini kita perlu meminjam pendekatan interaksi simboliknya Herbert Mead dan Herbert Blumer. Interaksi simbolik menawarkan pendekatan thing-meaning-action untuk mengerti perbuatan-perbuatan manusia dan bagaimana mereka berinteraksi satu sama lain. Untuk sekedar contoh saja, kalau ada orang tampar ibu kita [thing], tentu kita akan marah [action] karena ibu berarti buat kita [meaning]. Kita tidak akan bereaksi kalau yang ditampar adalah patung manekin karena ia tidak ada artinya buat kita. Inilah pendekatan interaksi simbolik. Pendekatan ini ada didasari oleh tiga premis. Pertama, bahwa manusia akan beraksi terhadap sesuatu perkara berdasarkan nilai perkara itu buat dirinya. Kedua, makna tersebut diperoleh dari hasil interaksi sosial. Ketiga, pemaknaan itu dapat diterima atau bahkan diubah melalui refleksi diri manusia saat berhubungan dengan berbagai peristiwa yang ia hadapi. Selengkapnya Blumer menjelaskan sebagai berikut:

The first premise is that human beings act toward things on the basis of the meanings of things have for them. .... The second premise is that the meaning of such things is derived from, or arises out of, the social interaction that one has with one's fellows. The third premise is that the meanings are handled in, and modified through, an interpretative process used by the person in dealing with the things he encounters (Blumer, 1969, p. 3).

Sebagai contoh, kasus penyembelihan sapi bagi Orang Islam dan Hindu di India Thing-nya sama yaitu sapi. Tapi meaning-nya beda untuk orang Islam dan Hindu.. Bagi orang India yang beragama Hindu sapi adalah dewa, menyembelih sapi adalah perbuatan nista. Bagi orang Islam di India menyembelih sapi adalah hal yang biasa, sapi adalah makanan halal, bahkan menyembelihnya di hari raya Idul Adha adalah ibadah. Oleh karena itu itu, berkali-kali terjadi bentrokan antara orang Islam dan Hindu di india, gara-gara penyembelihan sapi. Malah konon hal ini pula yang menyebabkan terpecahnya anak benua India menjadi negara India dengan Pakistan (Yang, 1980).

Dalam kasus larangan ibadah berjamaah pada saat PSBB, thing-mya adalah shalat berjamaah, shalat jum'at, shalat tarawih dan shalat idul fitri. Orang-orang yang taat beragama masih terus beraksi melaksanakan ibadah-ibadah tersebut di mesjid, karena hal itu sangat bermakna (meaningfull) buat mereka. Tindakan tersebut mungkin terlihat tidak rasonal dan penuh resiko. Namun dari persektif Thomas Carlyle dan Joahim Wach itulah ciri natural pengalaman beragama.Ia adalah sesuatu yang bermakna, yang akan terus dipertahankan oleh pelakunya dan tidak akan ditinggalkan. 


\section{Makna Ibadah Berjamaah dari Sudut Pandang Sosiologi}

Pemaknaan mengenai pentingnya beribadah di mesjid lahir dari interaksi sosial. Dakwahdakwah, ceramah-ceramah yang disampaikan oleh para pemuka agama selalu berulangkali menyebutkan pentingnya shalat berjamaah di masjid, shalat jumat, shalat tarawih dan shalat idul fitri. Hadits-hadits tentang pentingnya shalat-sholat tersebut berulang kali disampaikan melalui berbagai media. Ancaman meninggalkan shalat berjama'ah dan shalat jum'at pun berkali-kali disampaikan. Hal ini tertanam dalam benak kaum muslimin. Entah mereka melaksanakan atau tidak, tapi hampir semua tahu pentingnya ibadah berjamaah di masjid (Puslitbang Bimas Agama dan Layanan Keagamaan, 2020). Berulangkali mereka menyampaikan hadits Rasulullah Saw. tentang larangan meninggalkan shalat Jum'at dan meninggalkan shalat berjamaah di masjid.

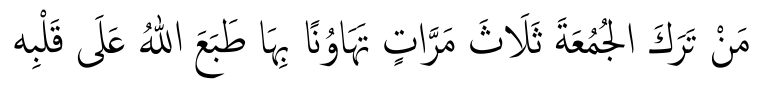

[Artinya, Siapa meninggalkan shalat Jumat tiga kali karena meremehkan, niscaya Allah menutup hatinya](Daud, 1952).

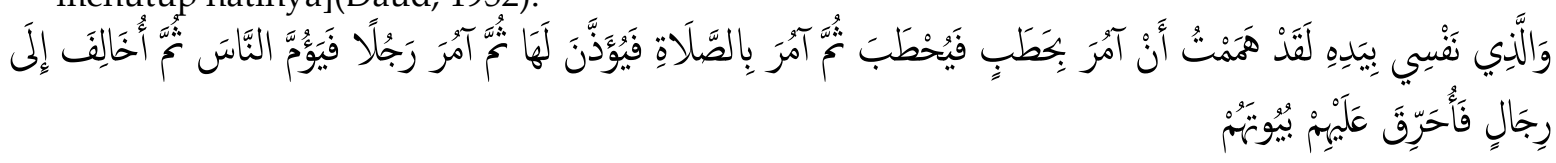

[Demi Allah yang nyawaku ada digengaman-Nya, aku sungguh ingin menuruh mengumpulkan kayu bakar hingga terkumpul, kemudian aku perintahkan shalat hingga berkumandanglah azan. Lalu aku perintahkan seseorang mengantikanku untuk mengimami shalat, sementara aku pergi memeriksa orang-orang yang tidak berjamaah, maka bakar rumah-rumah mereka](Bukhari, Ismail, t.t.).

Menurut teori interaksi simbolik, keterangan-keterangan seperti ini, setelah menjadi pengetahuan bersama, akan diproses oleh pribadi masing-masing dalam bentuk refleksi. Dari sanalah muncul dua kelompok. Pertama mereka yang taat melaksanakan dan terus mempertahankan beribadah bersama di masjid karena menganggapnya penting, kedua mereka yang tidak melaksanakan atau kurang taat melaksanakan dan hanya sesekali saja ikut shalat berjamaah di masjid karena mengganggapnya kurang atau bahkan tidak penting. Kelompok yang kedua ini sebagian ada yang tetap melaksanakan shalat secara individual (munfarid), sebagian lagi bahkan tidak melaksanakan shalat. Tapi baik yang melaksanakan dengan taat, yang melaksanakan sekali-kali maupun yang tidak melaksanakan sama sekali, semuanya sama-sama tahu kalau shalat berjamaah dan shalat jum'at adalah sesuatu yang harus dilaksanakan menurut standar ajaran agama Islam.

Itulah sebabnya, saat muncul larangan beribadah bersama di masjid, sebagaian kaum muslimin melasa galau. Apalagi saat MUI mengeluarkan larangan shalat berjam'ah dan shalat jum'at selama masa pandemic mereka kaget. Kekagetan bertambah ketika MUI juga mengeluarkan aturan agar shalat tarawih dan shalat Idul Fitri di masa pandemic COVID-19 dilakukan di rumah (Fatwa Majelis Ulama Indonesia (MUI) Nomor 28 Tahun 2020 tentang panduan kaifiat (tata cara) takbir dan shalat Idul Fitri Saat Pandemi COVID-19, 2020). Mengapa institusi ulama yang selama ini menyuruh mereka beribadah bersama di masjid, sekarang malah melarang? Benarkah fatwa ini?

Bagi kelompok yang kurang taat atau yang tidak taat yang memang selama ini jarang ke masjid proses refleksinya tidak lama. Mereka cepat menerima, malah mendapat semacam pembenaran dari MUI sebagai pemegang otoritas agama Islam atas perilaku mereka selama ini yang memang jarang shalat berjamaah di Mesjid. Namun bagi pemeluk agama yang taat proses refleksi untuk menerima atauran ini membutuhkan waktu yang lebih lama. Bahkan tidak jarang berakhir pada tindakan mengabaikan larangan, terutama dalam kasus shalat jum'at walaupun resikonya berat bahkan bisa mematikan.

\section{Shalat Berjamaah Bernuansa Social Distancing}

Pengabaian "larangan berkerumun" yang dilakukan umat Islam bukanlah pengabaian secara total. Para penganut agama Islam yang taat ini rupanya tidak kurang akal mencari cara untuk 
melaksanakan agama mereka sambil tetap aware dan care terhadap bahaya COVID-19 dan penyebarannya. Lalu muncullah semacam inovasi yakni shalat berjamaah bernuansa social dan physical distancing, yakni shalat berjama'ah yang dilakukan oleh para pesertanya sambil merenggangkan barisan dan menjaga jarak sekitar $1,5 \mathrm{~m}^{2}$ satu sama lain seperti pada gambar 1 . Secara fiqih shalat seperti ini keliru karena Rasulullah Saw. bersabda:

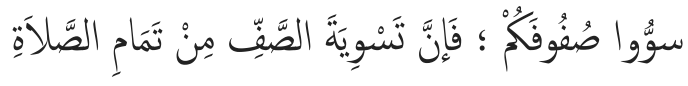
[Artinya: Luruskanlah shaf-shaf kalian, karena lurusnya shaf termasuk kesempurnaan shalat.] (Bukhari, Ismail, t.t.)

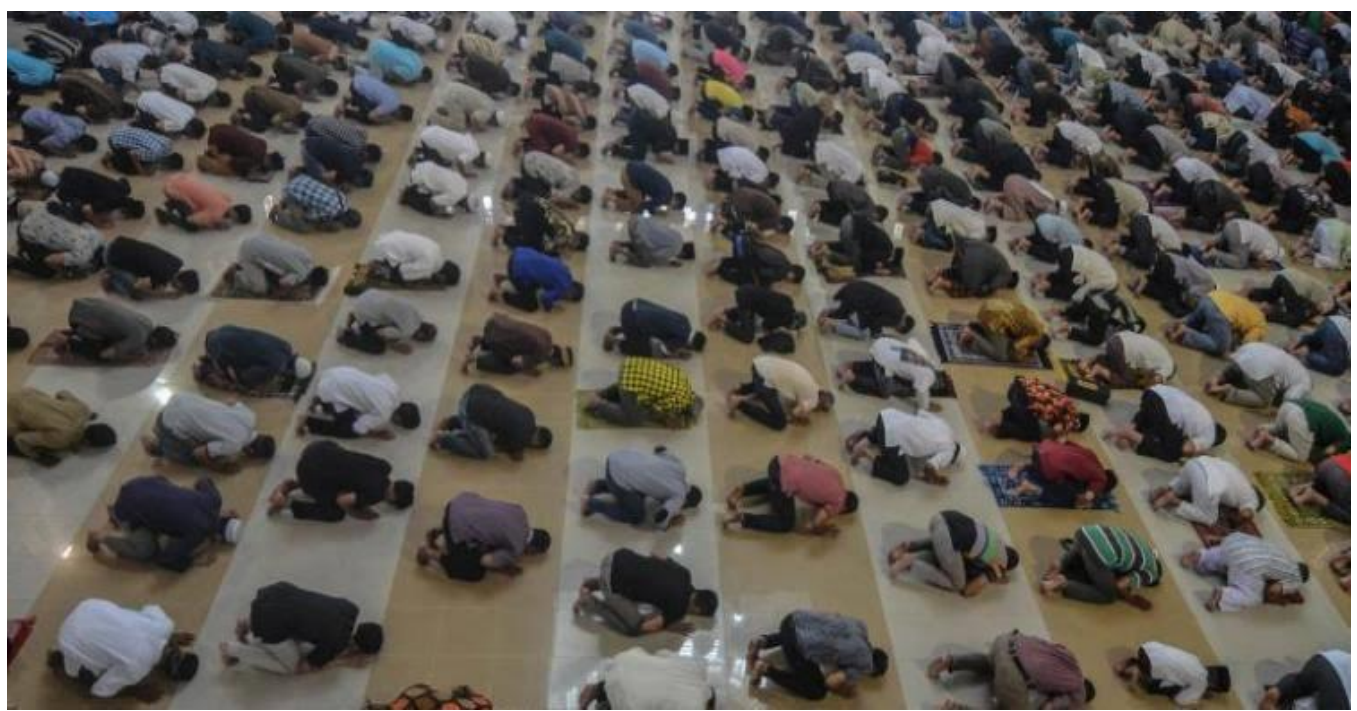

Gambar 1 Suasana Shalat Jamaah dalam keadaan Social Distancing

Berdasarkan hadist tersebut, shalat berjamaah seharusnya dilakukan dengan barisan yang rapat dan tidak meninggalkan celah sedikitpun, karena akan ditempati oleh setan. Tapi yang sekarang terjadi dalam shalat berjamaah bernuansa social distancing adalah sebaliknya. Orang-orang shalat berja'maah sambal berjauh-jauhan, seolah-olah shalat berjamaah bernuansa social distancing ini adalah kompromi antara keinginan untuk melaksanakan shalat berjamaah dan keharusan menjaga jarak karena pandemic COVID-19. Inilah hasil refleksi penganut agama Islam yang taat itu atas realitas yang sedang terjadi. Namun demikian patut diakui bahwa setelah berminggu-minggu pemerintah berkampanye mengenai perlunya social distancing dan menganjurkan masyarakat untuk bekerja di rumah dan beribadah di rumah, peserta shalat berjamaah di masjid-masjid pada umumnya mulai berkurang secara signifikan.

\section{Shalat Jum'at}

Pola shalat berjamaah bernuansa social distancing pada akhirnya juga diterapkan dalam pelaksanaan shalat jum'at. Shalat jumat umumnya dilakukan oleh peserta yang lebih banyak dari shalat berjamaah. Karena mereka yang tidak shalat berjamaah pun umumnya ikut shalat jumat. Sebagai ilustrasi, di masa normal sebelum pandemi COVID-19, masjid-mesjid besar seperti Mesjid Agung Bandung akan dipenuhi peserta shalat jum'at sampai ke teras masjid, padahal pada kegiatan shalat berjama' ah pesertanya hanya satu atau dua baris saja.

Di masa pandemic COVID-19, masjid-mesjid besar seperti Mesjid Agung Bandung ditutup dan tidak menyelenggarakan shalat jum'at, karena khawatir akan menjadi epicentrum penyebaran COVID-19 (Maklumat, Surat tertanggal 16 Maret 2020, Nomor : 050/S.M/DKM-MRB/III/2020, 2020). Peserta shalat jum'at pada akhirnya terdistribusi ke masjid-mesjid kecil yang tersembunyi di dalam 
komplek-komplek perumahan. Shalat jum'at dilaksanakan dengan memperhatikan jarak antar jamaah. Karpet-karpet yang biasa dijadikan alas shalat digulung dan dimasukkan gudang. Shalat sekarang hanya beralaskan lantai keramik yang secara berkala dibersihkan dengan disinsfektan seperti pada gambar 2. Tempat duduk masing-masing jama'ah ditandai dengan lakban yang ditempelkan di lantai masjid setiap 1 meter atau 1,5 meter. Tersedia pula hand sanitizer di luar masjid untuk para peserta shalat jumat. Sabun untuk cuci tangan juga tersedia di tempat wudhu dan kamar mandi. Tidak jarang dibagikan masker gratis untuk jama'ah shalat jumat.

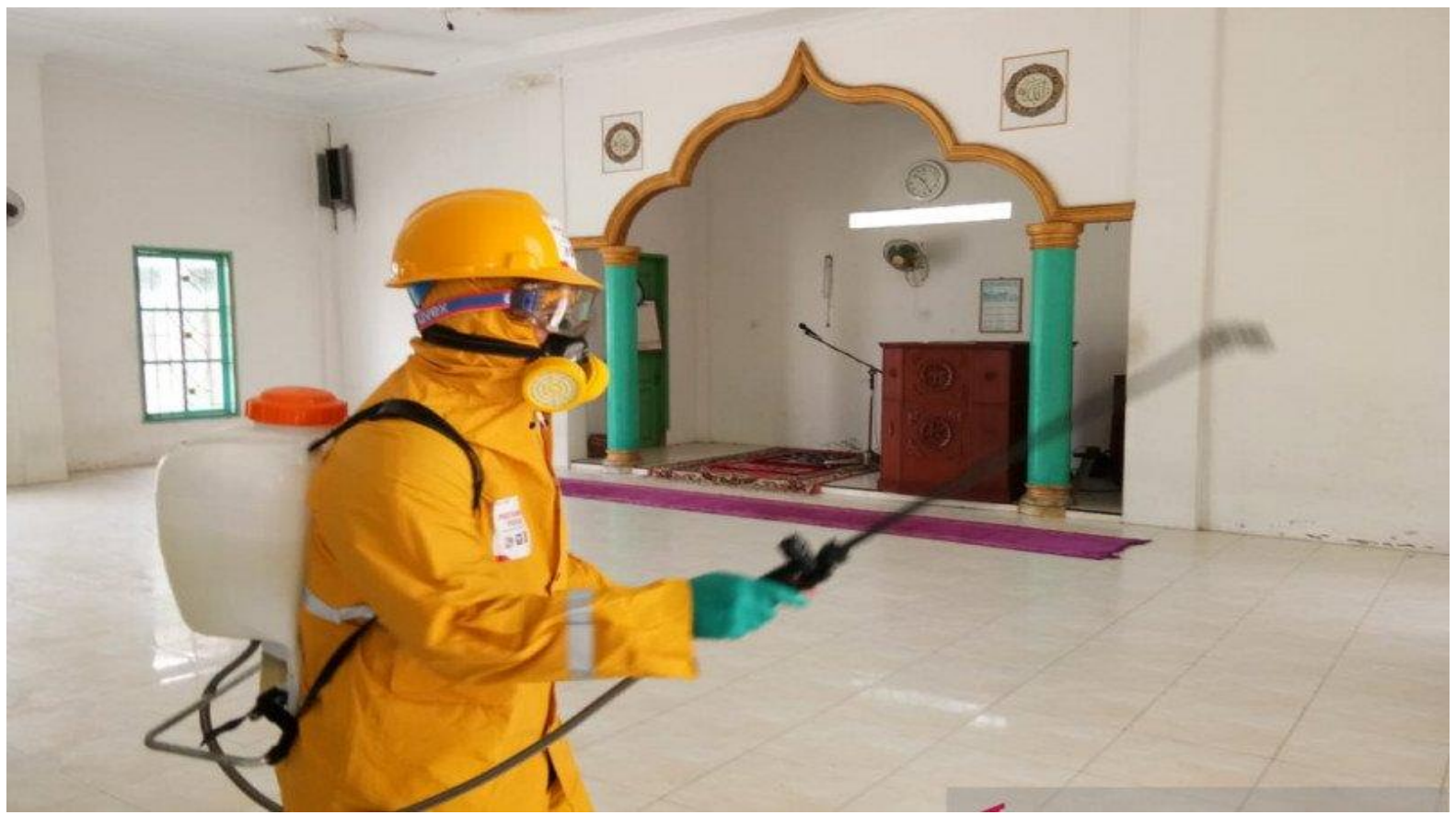

Gambar 2 Penyemprotan Disinfektan di masjid sebelum pelaksanaan Shalat Jum'at

Prosesi jumatan pun cendrung singkat. khutbah dan shalat jum'at dilaksanakan secara singkat dalam kisaran 10-15 menit saja. DKM biasanya berpesan kepada imam dan khatib agar mempersingkat khutbah dan bacaan shalat. Nampaknya semua menyadari kalau kegiatan itu sebenarnya beresiko tinggi dan sangat berbahaya kalau dilakukan terlalu lama. Sebagai konsekwensinya mereka melaksanakan kewajiban itu sesingkat mungkin, sekedar untuk menggugurkan kewajiban agama saja.

\section{Shalat Tarawih}

Yang paling tragis di masa pandemic COVID-19 adalah nasib shalat tarawih. Shalat ini biasanya dilaksanakan secara antusias oleh kaum muslimin di awal bulan Ramadhan. Peserta shalat tarawih di masjid-mesjid biasanya penuh sampai luber ke pelataran. Walaupun akhirnya terus menurun, hingga di akhir Ramadhan pesertanya hanya tinggal satu atau dua baris saja. Nampaknya pentingnya shalat tarawih ini kurang tertanam dalam kesadaran kaum muslimin. Barangkali karena hukumnya tidak wajib melainkan Sunnah, atau karena banyak umat Islam yang mengerjakannya secara pribadi di rumah, atau karena diakhir Ramadhan kaum muslimin biasanya sibuk pulang kampung. Namun demikian sepuluh malam pertama bulan Ramadhan masjid-masjid biasanya ramai dipenuhi orangorang yang melaksanakan shalat tarawih. laki-laki-perempuan, tua-muda semua tumpah ruah memenuhi masjid dengan khusyu mengikuti berbagai kegiatan yang dirancang oleh DKM masjid.

Di masa pandemic COVID-19 ini pemandangan tragis terlihat. Dari sejak awal peserta shalat tarawih berjama'ah di masjid dapat dihitung dengan jari (Mardianto, 2020). Kebanyakan umat Islam cendrung memilih untuk melaksanakan shalat tarawih di rumah saja sesuai anjuran pemerintah. 
Oleh karena itu, di malam-malam awal bulan Ramadhan masjid-mesjid terlihat lebih sepi dari tahuntahun sebelumnya. Peserta shalat tarawih di masjid terlihat hanya beberapa baris saja, itupun dengan jarak yang renggang antar peserta. Fenomena ini menunjukkan bahwa untuk ibadah-ibadah Sunnah yang bisa dilakukan sendiri, umat Islam cendrung memilih untuk melaksanakannya di rumah daripada di mesjid. Hanya untuk ibadah-ibadah yang memang harus dilaksanakan secara bersamasama mereka mau mengambil resiko dengan melaksanakannya secara bersama-sama di tempat ibadah.

\section{Shalat Idul Fitri}

Hantaman terbesar sebetulnya terjadi beberapa hari menjelang shalat Idul Fitri tiba. Karena pandemi COVID-19 ternyata belum juga berakhir,sejak enam hari sebelum lebaran pemerintah sudah mengeluarkan larangan shalat Idul Fitri di masjid dan lapangan dan menganjurkan masyarakat muslim untuk shalat Idul Fitri di rumah masing-masing (Peraturan Menteri Kesehatan Republik Indonesia nomor 9 tahun 2020 tentang pedoman pembatasan sosial berskala besar dalam rangka Percepatan Penanganan Corona Virus Deseas 2019 (COVID-19), 2020). Dampaknya umat Islam betulbetul merasakan kegelisahan dan kegalauan yang besar. Ini karena umat Islam yang sehari-hari tidak shalat sekalipun, ia akan shalat setahun sekali pada hari raya Idul Fitri. Larangan shalat Idul Fitri karena pandemi COVID-19, betul-betul menimbulkan kekacauan yang besar dalam relung batin umat Islam. Akibatnya, mayoritas masyarakat muslim akhirnya mengabaikan larangan pemerintah, dengan tetap menyelenggarakan shalat Idul Fitri di masjid-mesjid dan dilapangan terbuka, dengan pengaturan-pengatuan tertentu bernuansa social dan physical distancing, seperti dalam kasus shalat berjamaah, shalat jumat dan tarawih (Nuralam, 2020).

Sebagian umat Islam yang lainnya memilih untuk mentaati larangan pemerintah. Mereka melaksanakan shalat Idul Fitri di rumah bersama keluarga inti, sekitar 4 sampai 5 orang. Mereka mengikuti aturan tata cara shalat Idul Fitri di rumah yang telah disebar-luaskan secara masif melalui media massa beberapa hari sebelumnya (Fatwa Majelis Ulama Indonesia (MUI) Nomor 28 Tahun 2020 tentang panduan kaifiat (tata cara) takbir dan shalat Idul Fitri Saat Pandemi COVID-19, 2020). Namun tetap saja umat Islam yang melaksanakan shalat Idul Fitri di rumah mengeluh telah kehilangan momen lebaran mereka tahun ini (BBC, 2020).

Larangan shalat Idul Fitri, membuat umat merasakan kehilangan pengalaman keagaamaan mereka yang berharga. Tidak heran jika mayoritas umat Islam ada akhirnya mengabaikan larangan itu. Mereka bertaruh untuk keukeuh ikut shalat Idul Fitri bagaimanapun caranya, di manapun tempatnya, apapun resikonya. Shalat Idul Fitri adalah sesuatu yang sangat bermakna bagi mereka. Barangkali dari seluruh ritual ibadah umat Islam di Indonesia, shalat Idul Fitri inilah yang paling berkesan di hati mereka. Kegembiraaannya, kesyahduannya, kekhidmatan lautan manusia yang bersimpuh di hadapan ilahi, silaturahminya, tidak akan bisa mereka tinggalkan begitu saja. Pembangkangan masif terhadap aturan social dan physical distancing terlihat jelas di hari raya Idul Fitri $1441 \mathrm{H}$.

\section{Pola Sikap Keberagamaan Masyarakat Muslim dalam Menghadapi Wabah COVID-19}

Dari temuan-temuan tersebut, terkait sikap keberagamaan umat Islam di masa pandemic COVID-19 ditemukan satu pola yang menggabungkan empat buah varibel, yakni kewajiban agama, larangan berkerumun, partisipasi masyarakat dalam ritual ibadah berjamaah dan rasionalitas. Pola ini terlihat dalam dua survey yang dilakukan terkait pelaksanaan ibadah umat Islam selama pandemi COVID-19. Survey pertama dilakukan oleh Puslitbang Kementrian Agama RI (Puslitbang Bimas Agama dan Layanan Keagamaan, 2020). Survei tersebut melibatkan 18,743 resonden dari 34 provinsi di Indonesia yang dilakukan dalam kurun waktu 24-28 Aril 2020. Hasilnya cukup mengejutka. Meskipun 50,48 \% dari mereka tahu kalua mereka berada di wilayah andemi, ternyata 20,89\% dari mereka tetap nekad, berani mengambil resiko terpapar virus COVID-19. Ini artinya 2.000 dari 18.000 orang yang disurvei (1 berbanding 9 orang muslim) tetap melaksanakan ibadah 
berjamaah di masjid walaupun mereka tahu resikonya besar. Dalam hal ini rasio mereka kesampingkan demi iman pelaksanaan perintah tuhan.

Survei kedua dilakukan oleh kami untuk menguji keabsahan survey pertama dilapangan dalam skup yang lebih kecil. Survei sekaligus observasi dilakukan terhadap warga komplek dwipapuri Desa Cipadung, Kecamatan Cibiru, Kota Bandung, yang termasuk zona merah. Survey dilakukan tanggal 2 Mei 2020. Sementara observasi dilakukan sampai tanggal 24 Mei 2020. Hasilnya serupa dengan survei Balitbang Kementrian Agama RI. Dari 152 responden yang disurvei, sebanyak $79 \quad$ (51.9\%) di antaranya mengetahui bahwa Desa Cpadung termasuk zona merah. Sebanyak $13 \quad(8.55 \%)$ di antaranya masih suka shalat berjama'ah di masjid. Sebanyak $62(40.7 \%)$ di antaranya masih tetap ikut shalat Jum'at. Sebanyak 15 (9,86 \%) di antaranya sering ikut shalat tarawih berjamaah di masjid, dan semua responden (100\%) terbukti ikut shalat Idul Fitri $1441 \mathrm{H}$.

Data tersebut menunjukkan bahwa dalam kasus ibadah shalat berjamaah lima waktu yang sifatnya sangat dianjurkan untuk dilakukan secara berjamaah, partisipasi masyarakat dalam pelaksanaannya di masa pandemic ini bersifat sedang dibanding jumlah jama'ah sholat itu sebelum pandemi, masyarakat cenrdrung mentaati anjuran untuk beribadah di rumah untuk menghindari kerumunan. Masyarakat juga cendrung lebih bersikap rasional berupaya sedapat mungkin menghindar dari resiko terpapar COVID-19

Dalam kasus ibadah shalat jumat yang sifatnya wajib dilakukan secara berjamaah, partisiasi masyarakat dalam pelaksanaannya di masa pandemic COVID-19 cukup tinggi, masyarakat mengabaikan larangan berkerumun dan cendrung mengabaikan rasionalitas. Walaupun untuk sesaat, nampaknya mereka rela mengambil resiko ikut sholat jum'at, walupun sebagai akibatnya mungkin bakal terpapar COVID-19 karenanya.

Dalam kasus ibadah shalat tarawih berjamaah di masjid, yang sifatnya sunnah dan boleh dilakukan secara pribadi di rumah, partisipasi masyarakat dalam pelaksanaannya di masa pandemi ini bersipat rendah di banding tarawih tahun sebelumnya, masyarakat cendrung mentaati anjuran untuk melakukan social distancing dan beribadah di rumah guna menghindari kerumunan. Masyarakat juga cendrung lebih bersikap rasional berupaya sedapat mungkin menghindar dari resiko terpapar COVID-19

Anomali terjadi dalam kasus ibadah shalat Idul Fitri fitri. Walaupun level nya hanya ibadah Sunnah, namun ia harus dilakukan secara berjamaah, lagi pula masyarakat hanya mengalami khidmatnya pengalaman shalat Idul Fitri itu setahun sekali, maka sesuai prediksi, partisipasi masyarakat dalam pelaksanaannya di masa pandemic ini akan sangat tinggi, masyarakat cendrung mengabaikan anjuran untuk shalat Idul Fitri di rumah. Masyarakat juga cendrung lebih bersikap tidak rasional, dan rela mengambil resiko besar terpapar COVID-19 untuk ikut memikmati momen shalat iedul fitri tahun 1441 Hijriah/2020 Masehi ini.

\section{Simpulan}

Berdasarkan temuan-temuan yang sudah dibahas sebelumnya daatlah disimpulkan bahwa sikap keberagamaan masyarakat muslim di masa pandemi COVID-19 terbagi dua. Pertama, terkait ibadahibadah yang memang harus dilakukan secara bersama-sama (jama'ah) dan tidak bisa ditunda seperti shalat jum'at dan shalat Idul Fitri, partisipasi mereka masih tetap tinggi, mereka akan melaksanakan ibadah tersebut apapun resikonya, rasionalitas cendrung diabaikan, aturan social distancing akan diabaikan. Kedua, terkait ibadah-ibadah yang memang bisa dilakukan secara sendiri-sendiri (munfarid) seperti shalat lima waktu dan shalat tarawih, partisipasi mereka masih cendrung sangat rendah, mereka melaksanakan ibadah tersebut di rumah mereka masing-masing, rasionalitas mereka cenrdrung tinggi, aturan social distancing pun diperhatikan. 


\section{Referensi}

Abidah, A., Hidaayatullaah, H. N., Simamora, R. M., Fehabutar, D., \& Mutakinati, L. (2020). The Impact of Covid-19 to Indonesian Education and Its Relation to the Philosophy of "Merdeka Belajar." SiPoSE: Studies in Philosophy of Science and Education, 1(1), 38-49.

BBC. (2020). Idul Fitri: Pengalaman hari raya di tengah pandemi Covid-19 - "tidak terasa seperti Lebaran" dan 'ada yang hilang'. BBC. https://www.bbc.com/indonesia/indonesia-52633695

Bentzen, J. S. (2020). In Crisis, We Pray: Religiosity and the COVID-19 Pandemic. Covid Economics, 20, 52.

Blumer, H. (1969). Symbolic Interactionism: Perspective and Method. N.J.: Prentice-Hall.

Bukhari, Ismail, A. A. A. M. (n.d.). Shahih al-Bukhariy. Dar al-Fikr.

Cao, W., Fang, Z., Hou, G., Han, M., Xu, X., Dong, J., \& Zheng, J. (2020). The psychological impact of the COVID19 epidemic on college students in China. Psychiatry Research, 112934.

Carlyle, T. (2018). Heroes and Hero worship. Germany Outlokk Verlag GmbH.

Chen, S., Yang, J., Yang, W., Wang, C., \& Bärnighausen, T. (2020). COVID-19 control in China during mass population movements at New Year. The Lancet, 395(10226), 764-766. https://doi.org/10.1016/S01406736(20)30421-9

Cucinotta, D., \& Vanelli, M. (2020). WHO declares COVID-19 a pandemic. Acta Bio-Medica: Atenei Parmensis, 91(1), 157-160.

Daga, M. K., Kumar, N., Aarthi, J., Mawari, G., Garg, S., \& Rohatgi, I. (2019). From SARS-CoV to Coronavirus Disease 2019 (COVID-19)-A Brief Review. Journal of Advanced Research in Medicine (E-ISSN: 2349-7181 \& PISSN: 2394-7047), 6(4), 1-9.

Daud, A. (1952). Sunan Abi Daud. Maktabah Syarikah wa Matba'ah al-Musthafa.

Djalante, R., Lassa, J., Setiamarga, D., Sudjatma, A., Indrawan, M., Haryanto, B., Mahfud, C., Sinapoy, M. S., Djalante, S., Rafliana, I., Gunawan, L. A., Surtiari, G. A. K., \& Warsilah, H. (2020). Review and analysis of current responses to COVID-19 in Indonesia: Period of January to March 2020. Progress in Disaster Science, 6, 100091. https://doi.org/10.1016/j.pdisas.2020.100091

Maklumat, Surat tertanggal 16 Maret 2020, Nomor : 050/S.M/DKM-MRB/III/2020, (2020).

Fernandes, N. (2020). Economic effects of coronavirus outbreak (COVID-19) on the world economy. Available at SSRN 3557504.

Gössling, S., Scott, D., \& Hall, C. M. (2020). Pandemics, tourism and global change: a rapid assessment of COVID19. Journal of Sustainable Tourism, 1-20.

Guo, Y.-R., Cao, Q.-D., Hong, Z.-S., Tan, Y.-Y., Chen, S.-D., Jin, H.-J., Tan, K.-S., Wang, D.-Y., \& Yan, Y. (2020). The Origin, Transmission and Clinical Therapies on Coronavirus Disease 2019 (COVID-19) Outbreak - An Update on the Status. Military Medical Research, 7(11).

Ihsom, M. (2020). Gagal Paham Membandingkan Takut Corona dengan Takut Allah. NU Online. https:/www.nu.or.id/post/read/117930/gagal-paham-membandingkan-takut-corona-dengan-takut-allah

Peraturan Menteri Kesehatan Republik Indonesia nomor 9 tahun 2020 tentang pedoman pembatasan sosial berskala besar dalam rangka Percepatan Penanganan Corona Virus Deseas 2019 (COVID-19), (2020).

Fatwa Majelis Ulama Indonesia (MUI) Nomor 28 Tahun 2020 tentang panduan kaifiat (tata cara) takbir dan shalat Idul Fitri Saat Pandemi COVID-19, (2020).

Fatwa Majelis Ulama Indonesia Nomor: 14 Tahun 2020 Tentang Penyelenggaraan Ibadah dalam Situasi Terjadi wabah COVID-19, (2020).

Mardianto, R. (2020, April). Tarawih Malam Ini Masjid Sepi, Warga: Sedih, Enggak Bisa Berkata-kata. Riaumandiri.Id. https://www.riaumandiri.id/read/detail/84016/tarawih-malam-ini-masjid-sepi-warga-sedihenggak-bisa-berkatakata

Martha, J. (2020). Pemanfaatan Diplomasi Publik oleh Indonesia dalam Krisis Covid-19. Jurnal Ilmiah Hubungan Internasional, 121-130.

Nuralam, C. (2020). Tata Cara Melaksanakan Salat Idul Fitri di Rumah, Berjamaah Maupun Sendiri. Liputan 6. https://www.liputan6.com/bola/read/4261741/tata-cara-melaksanakan-salat-idul-fitri-di-rumah-berjamaahmaupun-sendiri

Peraturan Pemerintah Nomor 21 Tahun 2020 tentang Pembatasan Sosial Berskala Besar Dalam Rangka Percepatan Penanganan Corona Virus Disease 2019 (Covid-19), (2020).

Puslitbang Bimas Agama dan Layanan Keagamaan, B. dan D. K. A. R. (2020). Survei Pengetahuan, Sikap dan Tindakan Umat Beragama Menghadai Covid-19. Program Majelis Reboan Puslitbang Bimas Agama dan Layanan Keagamaan, Balitbang dan Diklat Kementerian Agama RI.

Spinelli, A., \& Pellino, G. (2020). COVID-19 pandemic: perspectives on an unfolding crisis. The British Journal of Surgery. 
Wach, J. (1996). Ilmu Perbandingan Agama (Djamannuri (ed.); Cetakan IV). Raja Grafindo Persada.

Woznitza, N., Hare, S. S., \& Nair, A. (2019). Covid-19 pandemic: Summary of current and emerging issues for radiographers. Work, 20.

Yang, A. A. (1980). Sacred symbol and sacred space in Rural India: Community mobilization in the "Anti-Cow Killing" riot of 1893. Comparative Studies in Society and History, 22(4), 576-596.

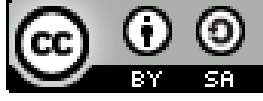

(C) 2020 by the authors. Submitted for possible open access publication under the terms and conditions of the Creative Commons Attribution (CC BY SA) license (https://creativecommons.org/licenses/by-sa/3.0/). 